\title{
Efficacy and Safety of Anti-Interleukin-5 Therapy in Patients with Asthma: A Systematic Review and Meta-Analysis
}

\author{
Fa-Ping Wang ${ }^{1 \oplus \ddagger}$, Ting Liu ${ }^{1 \oplus \ddagger}$, Zhu Lan ${ }^{2}$, Su-Yun Li ${ }^{3}$, Hui Mao ${ }^{1 *}$ \\ 1 Department of Respiratory Medicine, West China Hospital, Sichuan University, Chengdu, 610041, China, \\ 2 Department of Gynecology and Obstetrics, West China Second University Hospital, Sichuan University, \\ Chengdu, 610041, China, 3 Department of Respiratory Medicine, First Affiliated Hospital of Henan College of \\ Traditional Chinese Medicine, Zhengzhou, 450000, China \\ ه These authors contributed equally to this work. \\ $\ddagger$ These authors share the first authorship on this work. \\ * merrymh@126.com
}

\section{Abstract}

\section{Background}

\section{OPEN ACCESS}

Citation: Wang F-P, Liu T, Lan Z, Li S-Y, Mao H (2016) Efficacy and Safety of Anti-Interleukin-5 Therapy in Patients with Asthma: A Systematic Review and Meta-Analysis. PLoS ONE 11(11): e0166833. doi:10.1371/journal. pone. 0166833

Editor: Stelios Loukides, National and Kapodistrian University of Athens, GREECE

Received: September 5, 2016

Accepted: November 5, 2016

Published: November 22, 2016

Copyright: @ 2016 Wang et al. This is an open access article distributed under the terms of the Creative Commons Attribution License, which permits unrestricted use, distribution, and reproduction in any medium, provided the original author and source are credited.

Data Availability Statement: All relevant data are within the paper and its Supporting Information.

Funding: The authors received no specific funding for this work.

Competing Interests: The authors have declared that no competing interests exist.
Recent trials have assessed the efficacy and safety of novel monoclonal antibodies such as reslizumab and benralizumab. However, the overall efficacy and safety anti-interleukin (IL) 5 treatment in asthma have not been thoroughly assessed.

\section{Methods}

Randomized controlled trials (RCTs) of anti-IL-5 treatment on patients with asthma published up to October 2016 in PubMed, Embase, and Cochrane Central Register of Controlled Trials (CENTRAL) that reported pulmonary function, quality of life scores, asthmatic exacerbation rate, blood and sputum eosinophil counts, short-acting $\beta$-agonist (SABA) rescue use, and adverse events were included. The pooled mean difference, and relative risks (RR), and 95\% confidence intervals (Cls) were calculated using random-effects models.

\section{Results}

Twenty studies involving 7100 patients were identified. Pooled analysis revealed significant improvements in $\mathrm{FEV}_{1}$ (first second forced expiratory volume) (MD $=0.09,95 \% \mathrm{Cl}: 0.06-$ $\left.0.12, I^{2}=10 \%\right), \mathrm{FEV}_{1} \%\left(\mathrm{MD}=3.75,95 \% \mathrm{Cl}: 1.66-5.83,{ }^{2}=19 \%\right)$, Asthma Quality of Life Questionnaire (AQLQ) score (MD $=0.22,95 \% \mathrm{Cl}: 0.15-0.30, P^{2}=0 \%$ ), decreased blood, sputum eosinophils and asthmatic exacerbation $\left(\mathrm{RR}=0.66,95 \% \mathrm{Cl}: 0.59-0.73, P^{2}=51 \%\right)$; peak expiratory flow (PEF) (MD $\left.=5.45,95 \% \mathrm{Cl}:-2.83-13.72, I^{2}=0 \%\right)$, histamine $\mathrm{PC}_{20}$ (MD $\left.=-0.62,95 \% \mathrm{Cl}:-1.92-0.68, I^{2}=0 \%\right)$ or SABA rescue use (MD $=-0.11,95 \% \mathrm{Cl}:-0.3-$ $\left.0.07, P^{2}=30 \%\right)$ were unaffected; adverse events were not increased $(\mathrm{RR}=0.93,95 \% \mathrm{Cl}$ : $0.89-0.98, P^{2}=46 \%$ ). No publication bias was observed (Egger's $P=0.78$ ). 


\section{Conclusions}

Anti-interleukin 5 monoclonal therapies for asthma could be safe for slightly improving FEV $\mathrm{F}_{1}$ (or $\mathrm{FEV}_{1} \%$ of predicted value), quality of life, and reducing exacerbations risk and blood and sputum eosinophils, but have no significant effect on PEF, histamine PC20, and SABA rescue use. Further trials required to establish to clarify the optimal antibody for different patients.

\section{Introduction}

Asthma is a common chronic inflammatory disease that affects more than 300 million people worldwide, and imposes a high disease burden and economic impact globally [1-3]. Despite taking high-dosage inhaled corticosteroids according to the Global Initiative for Asthma (GINA) guidelines, at least $40 \%$ of patients continue to suffer from inadequately controlled symptoms, either because they are truly resistant or because they do not take them $[4,5]$. Patients who remain uncontrolled can use other drugs such as leukotriene-receptor antagonists, slow-release theophylline, and long-acting anticholinergics [6]. Since the anti-immunoglobulin (Ig)E humanized monoclonal antibody omalizumab became the first biological treatment approved for treating allergic asthma, many small molecules and monoclonal antibodies targeting biomolecular specificities have been investigated for treating symptomatic asthma [7]. Eosinophilic inflammatory infiltration is a central event in asthma pathogenesis. IL-5 is the chief cytokine responsible for eosinophil production, survival, maturation and recruitment and activation at allergic inflammation sites [8]. Preclinical studies have demonstrated a key role for IL-5 in murine models of allergen-induced airway eosinophilia and hyperresponsiveness [9]. Given the relationship of IL-5 to eosinophilia and asthma severity, human(ized) monoclonal antibodies targeting IL- 5 have shown great promise in severe refractory asthma with persistent eosinophilia $[10,11]$. The anti-IL-5 agents benralizumab, reslizumab, and mepolizumab have been investigated for treating asthma [12, 13]. However, their effects on lung function (especially $\mathrm{FEV}_{1}$ ) have been less consistent. Here, we conducted a meta-analysis of randomized, controlled trials (RCTs) to assess whether anti-IL-5 monoclonal antibodies therapy is safe and effective in patients (more than 12 years) with asthma.

\section{Methods}

\section{Literature searches and study selection}

PubMed, Embase, and the Cochrane Central Register of Controlled Trials (CENTRAL) were searched for articles published from 1946 to October 2016, using the search terms: "anti-interleukin-5" or "mepolizumab" or "benralizumab" or "reslizumab" or "monoclonal antibody" or "anti-IL-5", combined with "asthma". Language restrictions were not applied. Reviews and the reference lists of relevant articles were also screened for additional articles of interest. Two independent authors (FPW and TL) screened all references according to the selection criteria. To ensure a complete review of the available studies, the abstracts of relevant scientific meetings were also examined, but trials published solely in abstract form were excluded. Any disagreements were resolved by consensus with a third author when necessary. The details of the search strategy are displayed in S1 Table. 


\section{Inclusion and exclusion criteria}

Eligible clinical trials were defined as: (1) adults/adolescents ( $\geq 12$ years) with diagnosis of asthma; (2) investigations of patients who received anti-interleukin-5 monoclonal antibody therapy at any dose, placebo-controlled or standard therapy; (3) randomized (parallel group) placebo-controlled trials, and (4) RCTs reporting the following outcomes: blood and sputum eosinophil count, asthma exacerbation, lung function, asthma control and quality of life scores, rescue use of SABA and adverse events. We excluded non-randomized, observational, cohort, case-control and non-blinded clinical trials. FPW and TL independently screened all references according to the selection criteria. Differences in opinion about inclusion were resolved by mutual agreement and arbitration of a third author (HM).

\section{Data extraction and quality assessment}

FPW and TL independently extracted related data in blinded fashion from eligible studies based on the predefined criteria, which included the characteristics of the trials, interventions, and outcomes. The predefined primary outcomes were lung function [first second forced expiratory volume $\left(\mathrm{FEV}_{1}\right), \mathrm{FEV}_{1} \%$ of predicted value, peak expiratory flow (PEF), histamine $\mathrm{PC}_{20}$ ], the Asthma Quality of Life Questionnaire (AQLQ) scores, and asthma exacerbation. Asthma exacerbation was defined as a worsening of asthma requiring increased corticosteroids or albuterol dose to control symptoms and/or the need for asthma-related emergency treatment/hospitalization. Secondary outcomes were adverse events and efficacy outcomes [blood eosinophil count, sputum eosinophils (\%), short-acting $\beta$-agonist (SABA) rescue use]. The risk of bias was assessed using Cochrane-recommended tools, which included: (1) adequate sequence generation; (2) allocation concealment; (3) blinding; (4) incomplete outcome data addressed; (5) free of selective reporting; and (6) free of other bias [14].

\section{Statistical analyses}

All analyses were performed with Review Manager (Version 5.3, The Cochrane Collaboration) and Stata (Version 12.0, Stata Corporation, USA), $P<0.05$ was considered statistically significant. If a study presented more than two interventions, we combined two or three intervention groups into a single intervention group in accordance with the Cochrane handbook. ${ }^{9}$ Random-effects model was applied in all data analyses regardless of statistical heterogeneity. Risk ratio (RR) and 95\% CIs were used to analyze dichotomous data, and mean difference and 95\% CI were used for continuous data. Heterogeneity assumptions were assessed using the $I^{2}$ statistic $\left(I^{2}>50 \%\right.$ indicates significant heterogeneity), and tested with the $\chi^{2}$ statistic $(P<0.05)$. However, the number of studies affects both the power of the heterogeneity test and the heterogeneity measures $I^{2}$, but not $H_{M}^{2}$ [15]. In order to the increase the power of detecting heterogeneity, the $95 \%$ CI of $I^{2}$ and $H_{M}^{2}$ were calculated [15-17]. If substantial heterogeneity was identified, subgroup and sensitivity analyses were performed. Moreover, we separately performed subanalyses in different drugs for each outcome. Publication bias was determined using the Begg's funnel plot and assessed by Egger's test if the number of the studies was larger than ten.

\section{Results}

\section{Study characteristics}

We identified 3047 manuscripts: 2019 from PubMed, 893 from Embase, 135 from CENTRAL. Based on title/abstract and full-text screening, 20 RCTs were included in the meta-analysis. Fig 1 summarized the study selection process [18-37]. 


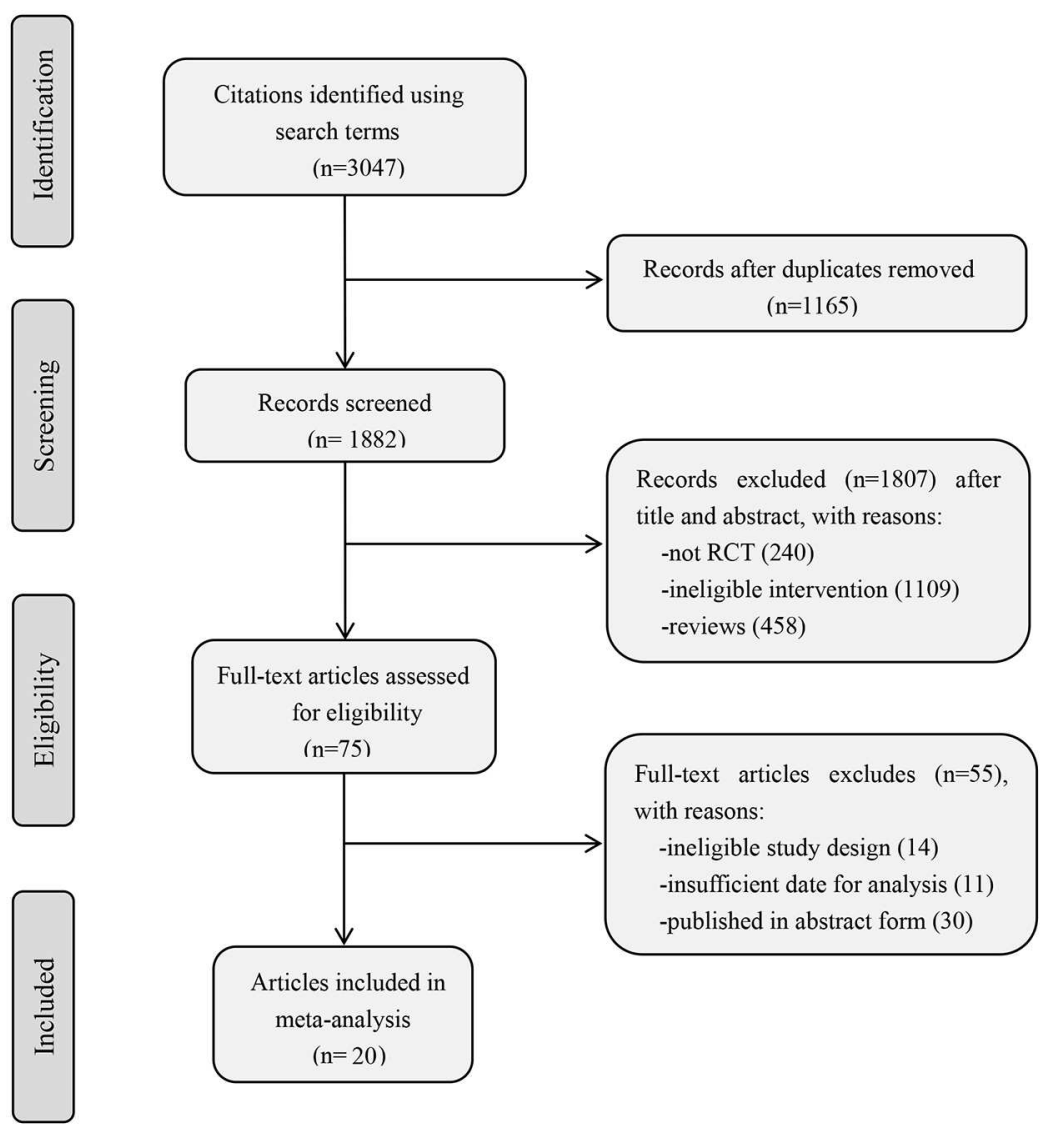

Fig 1. Flow chart of study identification, inclusion, and exclusion.

doi:10.1371/journal.pone.0166833.g001

Tables 1-3 lists the RCT characteristics, and Table 4 describes the baseline characteristics of the patients enrolled. Sample sizes ranged from 19 to 1306 subjects. Nine, five, and six trials used mepolizumab [18-26], reslizumab [27-31], and benralizumab [32-37], respectively. Treatment duration ranged from 1 day to 56 weeks and follow-up ranged from 12 to 56 weeks. Seven studies administered drugs used subcutaneous injection [25, 26, 32, 33, 35-37], while the remaining studies used intravenous infusion [18-24, 27-31,34]. Nine studies involved patients with severe/refractory asthma [22-28, 36, 37]; four studies included patients with mild, mild to moderate, or moderate asthma [18-21]; the remaining studies did not specify asthma severity [29-35]. Corren et al. [30] and Castro et al. [33] studied patients with noneosinophilic asthma.

\section{Primary outcomes}

Lung function. $\quad F E V_{1}$. Fourteen studies assessed $\mathrm{FEV}_{1}$ responsiveness to anti-interleukin 5 treatment [19,21-24,26,28-31,33,34,36,37]. Six studies reported significant improvements in FEV1 between mepolizumab, reslizumab, and benralizumab treatments and placebo, while the remaining studies reported no effect on FEV1. Fig 2 showed that reslizumab was more effective than other two anti-interleukin 5 monoclonal antibodies in improving $\mathrm{FEV}_{1}(\mathrm{MD}=0.12$, 95\% CI: $0.04-0.19, P=0.002)$, and the pooled data analysis revealed a slight improvement $(\mathrm{MD}=0.09,95 \% \mathrm{CI}: 0.06-0.12, P<0.001)$. There was minimal heterogeneity $\left(I^{2}=10 \%\right.$, $P=0.34,95 \%$ CI $-53 \%$ to $\left.47 \%, H_{M}^{2}=0.10\right)$. 


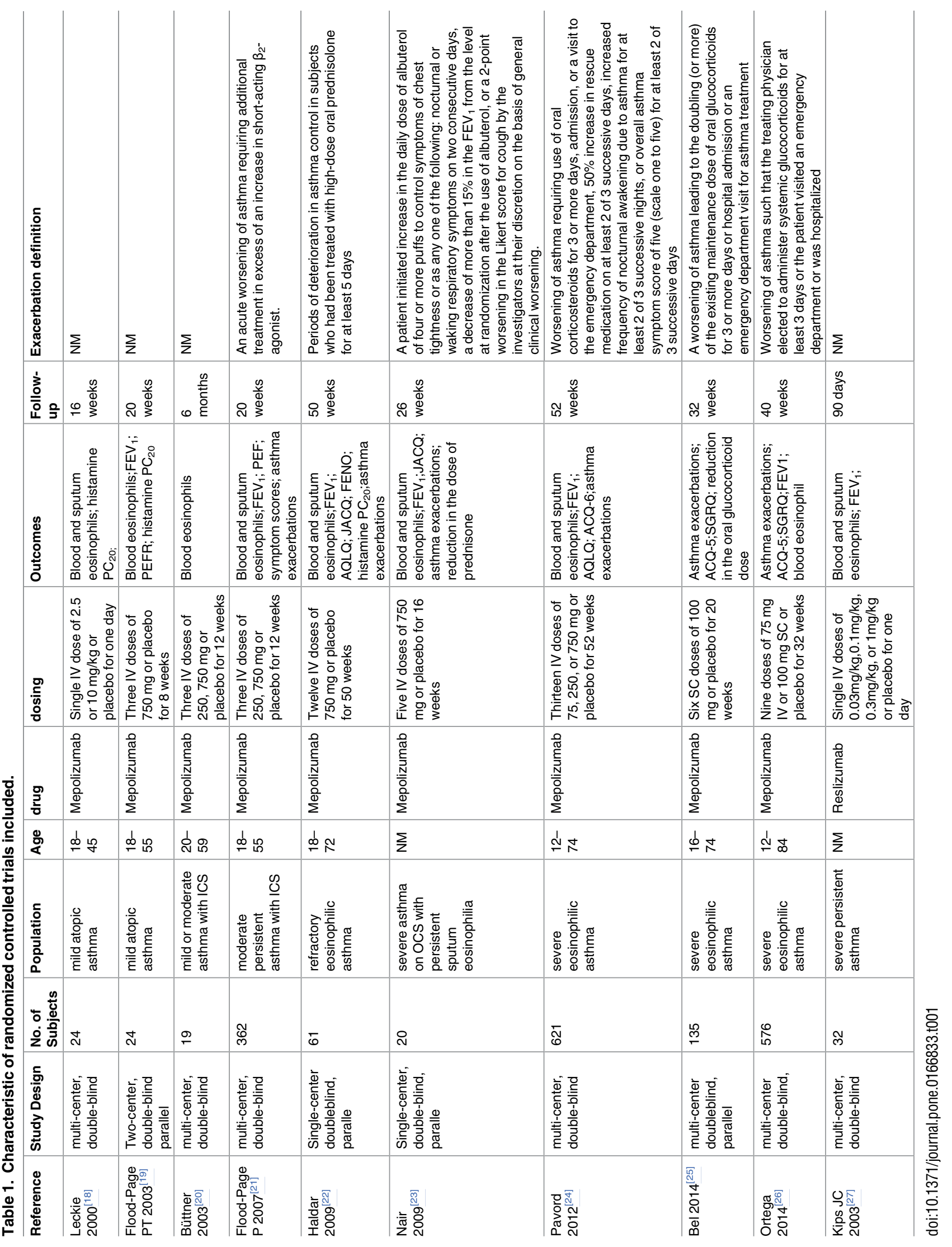




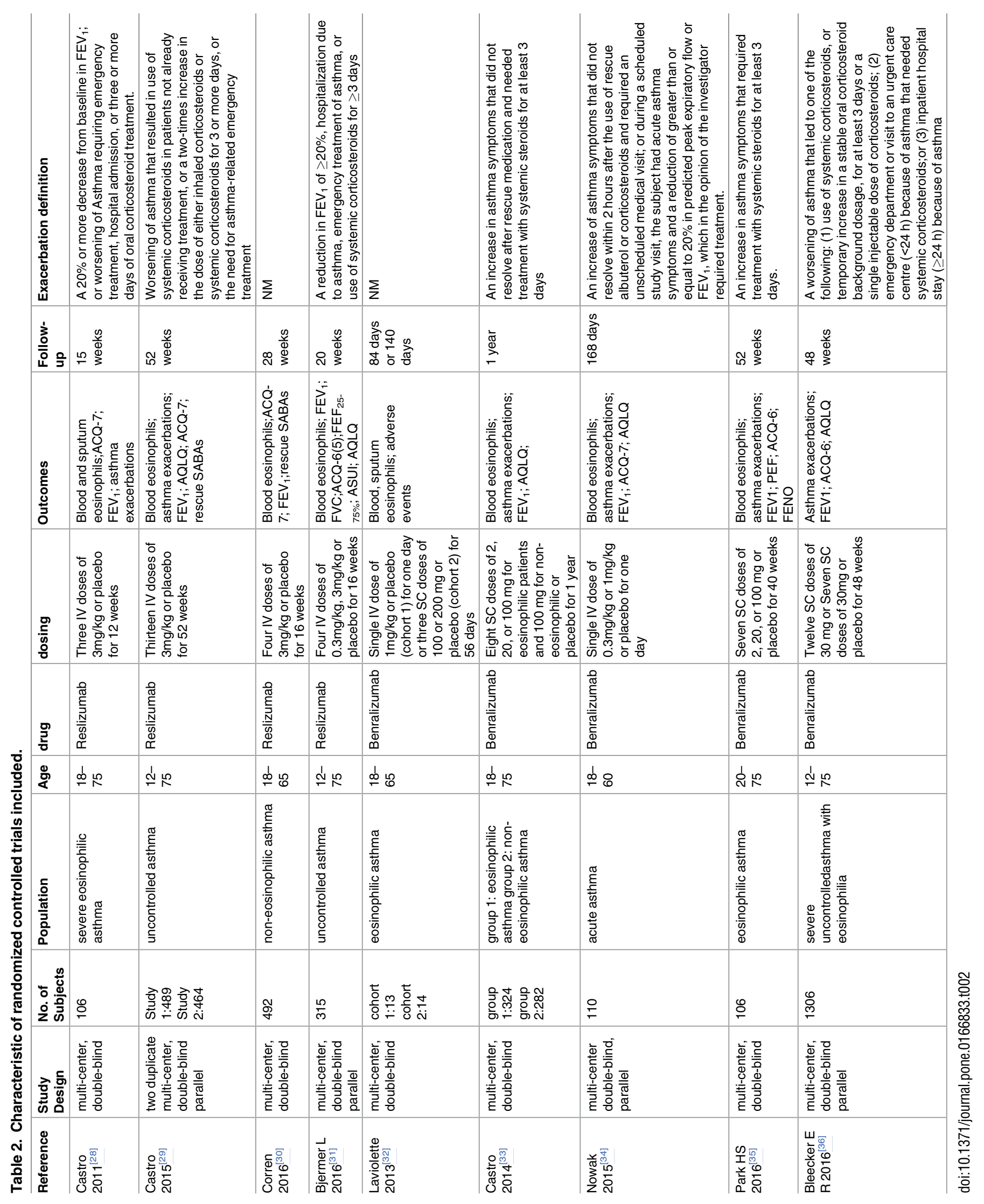


Table 3. Characteristic of randomized controlled trials included.

\begin{tabular}{l|l|l|l|l|l|l|l|l|l}
\hline Reference & $\begin{array}{l}\text { Study } \\
\text { Design }\end{array}$ & $\begin{array}{l}\text { No. of } \\
\text { Subjects }\end{array}$ & Population & Age & drug & dosing & Outcomes & $\begin{array}{l}\text { Follow- } \\
\text { up }\end{array}$ & Exacerbation definition \\
\hline $\begin{array}{l}\text { FitzGerald } \\
\text { J M }\end{array}$ & $\begin{array}{l}\text { multi- } \\
\text { center, } \\
\text { double- } \\
\text { blind } \\
\text { parallel }\end{array}$ & 1205 & $\begin{array}{l}\text { severe, } \\
\text { uncontrolled, } \\
\text { eosinophilic } \\
\text { asthma }\end{array}$ & $\begin{array}{l}12- \\
75\end{array}$ & Benralizumab & $\begin{array}{l}\text { Fourteen SC } \\
\text { doses of 30mg } \\
\text { or Eight SC } \\
\text { doses of 30mg } \\
\text { or placebo for } \\
56 \text { weeks }\end{array}$ & $\begin{array}{l}\text { Asthma } \\
\text { exacerbations; } \\
\text { FEV1; ACQ-6; } \\
\text { AQLQ }\end{array}$ & $\begin{array}{l}\text { 56 } \\
\text { weeks }\end{array}$ & $\begin{array}{l}\text { An asthma exacerbation was } \\
\text { defined as a worsening of asthma } \\
\text { that led to one of the following: (1) } \\
\text { use of systemic corticosteroids for 3 } \\
\text { days or more or a temporary } \\
\text { increase in a stable, background } \\
\text { dosage of oral corticosteroids; (2) } \\
\text { an emergency department or urgent } \\
\text { care visit (<24 h) due to asthma that } \\
\text { required systemic corticosteroids; } \\
\text { or (3) an inpatient admission to } \\
\text { hospital }(\geq 24 \mathrm{~h}) \text { due to asthma. }\end{array}$ \\
\hline
\end{tabular}

FEV1, forced expiratory volume in 1 second; PEF, peak expiratory flow; histamine PC20, provocative concentration of histamine required to cause a $20 \%$ fall in FEV1; JACQ, Juniper Asthma Control Questionnaire; AQLQ, the Asthma Quality of Life Questionnaire; ACQ, Asthma Control Questionnaire; FeNO, fraction of exhaled nitric oxide; SABAs: short-acting beta-agonists (SABAs); SC: subcutaneous injections; IV, intravenous; ICS, inhaled corticosteroid; OCS, oral corticosteroid; NM: not mentioned

FEV $_{\mathbf{1}} \%$ of predicted value. Seven trials using three different anti-interleukin 5 antibodies reported $\mathrm{FEV}_{1} \%$ of predicted value [23,25-28,34,35]. Overall, anti-interleukin 5 treatment was associated with modestly improved in $\mathrm{FEV}_{1} \%$ of predicted value compared to placebo $(\mathrm{MD}=3.75,95 \%$ CI 1.66-5.83, $P=0.0004)$ (Fig 3), and heterogeneity was not statistically significant $\left(I^{2}=19 \%, \mathrm{P}=0.29,95 \% \mathrm{CI} 0 \%\right.$ to $\left.62 \%, H_{M}^{2}=0.23\right)$. When looking at subgroups, there were no differences by benralizumab ( $\mathrm{MD}=-0.88,95 \% \mathrm{CI}-6.88-5.13, P=0.78)$.

Peak expiratory flow (PEF) and Provocative concentration of histamine (histamine $\mathbf{P C}_{\mathbf{2 0}}$ ). Four trials depicted PEF change after anti-interleukin 5 treatment $[19,21,34,35]$, and only three about mepolizumab studies reported the results in histamine $\mathrm{PC}_{20}[18,19,22]$. Results from the pooled data illustrated that anti-interleukin 5 could not significantly improve PEF (MD = 5.45, 95\% CI: -2.83-13.72, $P=0.2$ ) (Fig 4) or $\mathrm{PC}_{20}(\mathrm{MD}=-0.62$, 95\% CI: $-1.92-$ $0.68, P=0.35$ ) (Fig 5). Studies were highly homogeneous $\left(I^{2}=0 \%, P=0.73,95 \% \mathrm{CI} 0 \%\right.$ to $84 \%, H_{M}^{2}=0 ; I^{2}=0 \%, P=0.73,95 \%$ CI $0 \%$ to $\left.89 \%, H_{M}^{2}=0\right)$. Our confidence in these results is low due to the wide CI.

Asthma Quality of Life Questionnaire (AQLQ) score. Eight trials of three different antiinterleukin 5 antibodies reported AQLQ scores [22,24,29,31,33,34,36,37]. Pooled analysis showed that anti-interleukin 5 treatment was associated with significantly improved AQLQ score $(\mathrm{MD}=0.22,95 \%$ CI $0.15-0.30, P<0.001)$, with no significant heterogeneity $\left(I^{2}=0 \%\right.$, $P=0.94,95 \%$ CI 0\% to 29\%, $H_{M}^{2}=-0.64$ ) (Fig 6). Among subgroups, AQLQ scores improved only in the trials involving reslizumab and benralizumab treatment trials $(\mathrm{MD}=0.27,95 \% \mathrm{CI}$ $0.13-0.42, P=0.0002 ; \mathrm{MD}=0.21,95 \%$ CI $0.11-0.31, P<0.001)$, but not mepolizumab $(P=0.08)$.

Asthma exacerbations. Thirteen studies (6,072 participants) reported on asthma exacerbations [21-29,33,34,36,37]. Table 1 summarizes their definitions for asthma exacerbation. Although these definitions varied, all 13 studies defined exacerbation based on increased corticosteroids or albuterol dose to control symptoms and/or the need for asthma-related emergency treatment/hospitalization. Fig 7 showed that anti-interleukin 5 monoclonal therapies were associated with a significant reduction in asthmatic exacerbation compared with placebo ( $\mathrm{RR}=0.66,95 \% \mathrm{CI}, 0.59-0.73, P<0.001)$, but the reporting was significantly heterogeneous $\left(I^{2}=51 \%, P<0.001,95 \%\right.$ CI $12 \%$ to $\left.73 \%, H_{M}^{2}=1.05\right)$. 
Table 4. Baseline Characteristics of Patients in the 20 Studies Included.

\begin{tabular}{|c|c|c|c|c|c|c|c|}
\hline Refs. & No. * & Sex & Age & Blood Eosinophils & FEV $_{1} \%$ Predicted & $\begin{array}{l}\text { Diagnosis of } \\
\text { asthma }\end{array}$ & PEF \\
\hline & & (Male, \%)* & (Mean SD, y)* & (Mean SD, $10^{3} / \mathrm{uL}$ )* & (Mean SD, \%) * & (mean SD, y)* & $\begin{array}{l}\text { (Mean SD, } \\
\text { L/min)* }\end{array}$ \\
\hline${\text { Leckie } 2000^{[18]}}$ & 16 & NM & 29 (6.29) & $0.25(0.1)$ & $86.15(9.58)$ & NM & NM \\
\hline Flood-Page PT $2003^{[19]}$ & 11 & $9(82)$ & $31(5.5)$ & $0.27(0.18)$ & $87.0(6.3)$ & NM & $433(37.8)$ \\
\hline Büttner $2003^{[20]}$ & 12 & $5(42)$ & $44.25(10.85)$ & NM & $65.68(10.48)$ & $11.75(9.27)$ & NM \\
\hline Flood-Page P 2007 ${ }^{[21]}$ & 236 & $112(47)$ & $36(29.4)$ & $0.35(0.25)$ & $68.35(9.2)$ & NM & $\begin{array}{l}366.6 \\
(90.0)\end{array}$ \\
\hline Haldar 2009 22$]$ & 29 & $14(48)$ & $48(7)$ & $0.32(0.38)^{\&}$ & $78.1(20.9)$ & NM & NM \\
\hline Nair 2009 ${ }^{[23]}$ & 9 & $4(44)$ & $56.4(10.9)$ & $0.68(0.52)$ & $66.6(18.3)$ & NM & NM \\
\hline Pavord $2012^{[24]}$ & 461 & $171(37)$ & $49.4(11.2)$ & $0.24(1.03)^{\#}$ & $60.0(16.3)$ & $19.5(14.4)$ & NM \\
\hline Bel 2014 & 69 & $25(36)$ & $50(9.7)$ & $0.25(1.245)^{\#}$ & $59.6(17.0)$ & $17.4(11.8)$ & NM \\
\hline Ortega $2014^{[26]}$ & 385 & $163(42)$ & $50.5(11.5)$ & $0.285(1.018)^{\#}$ & $60.3(17.9)$ & $20.2(13.4)$ & $262(110)$ \\
\hline Kips JC $2003^{[27]}$ & 18 & $12(67)$ & $43(5.9)$ & $0.26(0.04)$ & $53.4(7.6)$ & NM & NM \\
\hline Castro $2011^{[28]}$ & 53 & $19(36)$ & $44.9(13.94)$ & NM & $66.0(15.16)$ & $23.3(11.38)$ & NM \\
\hline Castro $2015^{[29]}$ & $\begin{array}{l}\text { Study 1: } \\
245 \text { Study } \\
\text { 2: } 232 \\
\end{array}$ & $\begin{array}{l}\text { Study 1: } 103 \\
\text { (42) Study 2: } \\
88(38)\end{array}$ & $\begin{array}{l}\text { Study 1: } 48 \\
\text { (14.1) Study 2: } \\
48(14.4)\end{array}$ & $\begin{array}{l}\text { Study 1:0.696 } \\
(0.768) \text { Study 2: } 0.61 \\
(0.412)\end{array}$ & $\begin{array}{l}\text { Study 1:63.6 } \\
\text { (18.6) Study } \\
2: 70.4(21.0)\end{array}$ & $\begin{array}{l}\text { Study 1:19.7 (15.2) } \\
\text { Study 2:18.2 (14.4) }\end{array}$ & NM \\
\hline Corren 2016 $6^{[30]}$ & 398 & $137(34)$ & 44.9 & $0.281(0.264)$ & 66.8 & 26.2 & NM \\
\hline Bjermer L 2016 ${ }^{[31]}$ & 210 & $85(40)$ & 43.7 & $0.65(0.006)$ & 69.6 & 20.2 & NM \\
\hline Laviolette $2013^{[32]}$ & $\begin{array}{l}\text { cohort 1: } 8 \\
\text { cohort 2: } 9\end{array}$ & $\begin{array}{l}\text { cohort } 1: 6 \\
(25) \text { cohort } 2: \\
5(56)\end{array}$ & $\begin{array}{l}\text { cohort 1: } 38.9 \\
\text { (14.7) cohort 2: } \\
38.9(13.8)\end{array}$ & NM & $\begin{array}{l}\text { cohort 1: } 70.5 \\
\text { (15.6) cohort 2: } \\
68.7(11.4)\end{array}$ & NM & NM \\
\hline Castro 2014 ${ }^{[33]}$ & $\begin{array}{l}\text { group 1: } \\
244 \text { group } \\
\text { 2: } 140\end{array}$ & $\begin{array}{l}\text { group 1: } 78 \\
\text { (32) group 2: } \\
42(30)\end{array}$ & $\begin{array}{l}\text { group 1: } 47.2 \\
\text { (12.9) group 2: } \\
50.0(11.5)\end{array}$ & $\begin{array}{l}\text { group 1: } 0.54(0.32) \\
\text { group 2: } 0.19(0.12)\end{array}$ & $\begin{array}{l}\text { group 1: } 65.3 \\
\text { (15.3) group 2: } \\
66.8(15.1)\end{array}$ & NM & NM \\
\hline Nowak $2015^{[34]}$ & 72 & $25(35)$ & $36.3(6.8)$ & $0.213(0.393)$ & 58.1 & NM & NM \\
\hline Park HS 2016 ${ }^{[35]}$ & 77 & $29(38)$ & $53.4(11.5)$ & $0.72(0.87)$ & $67.8(14.4)$ & NM & NM \\
\hline Bleecker E R 2016 ${ }^{[36]}$ & 797 & $270(34)$ & $48.9(14)$ & $0.34(0.52)$ & $56.8(14.4)$ & 14.9 & NM \\
\hline FitzGerald J M 2016 ${ }^{[37]}$ & 866 & $323(37)$ & $49.5(14)$ & $0.39(0.42)$ & 58.4(14.9) & 16.3 & NM \\
\hline
\end{tabular}

*Data on all patients who received anti-interleukin 5, and all data are $\mathrm{n}(\%)$ or mean (SD), unless otherwise stated.

\#Geometric mean on loge scale.

\&geometric means $\pm \log 10 \mathrm{SD}$.

NM: Not Mentioned

doi:10.1371/journal.pone.0166833.t004

\section{Secondary outcomes}

Blood and sputum eosinophils. 18 trials included blood eosinophil analysis and six trials compared sputum eosinophil levels between anti-interleukin 5 treatment and placebo [18,22$24,28,32]$. As the data were reported inconsistently (data were shown as median [range], mean [SD] or geometric mean $[\log 10 \mathrm{SE}])$, we did not obtain a synthesized analysis of the outcomes. However, from all the results reported, a similar outcome was identified that anti-interleukin 5 significantly decreased blood and sputum eosinophils compared with placebo (S2 Table).

SABA rescue use. Four trials evaluated the effect of anti-interleukin 5 antibodies on SABA use (Fig 8) [21,29-31]. Analyses of these studies showed a non-significant decrease in the anti-interleukin 5 group compared with the placebo group ( $\mathrm{MD}=-0.11,95 \% \mathrm{CI}-0.3-0.07$, $P=0.22)$, with low heterogeneity $\left(I^{2}=11 \%, P=0.34,95 \%\right.$ CI $0 \%$ to $\left.54 \%, H_{M}^{2}=0.13\right)$ among the studies. 


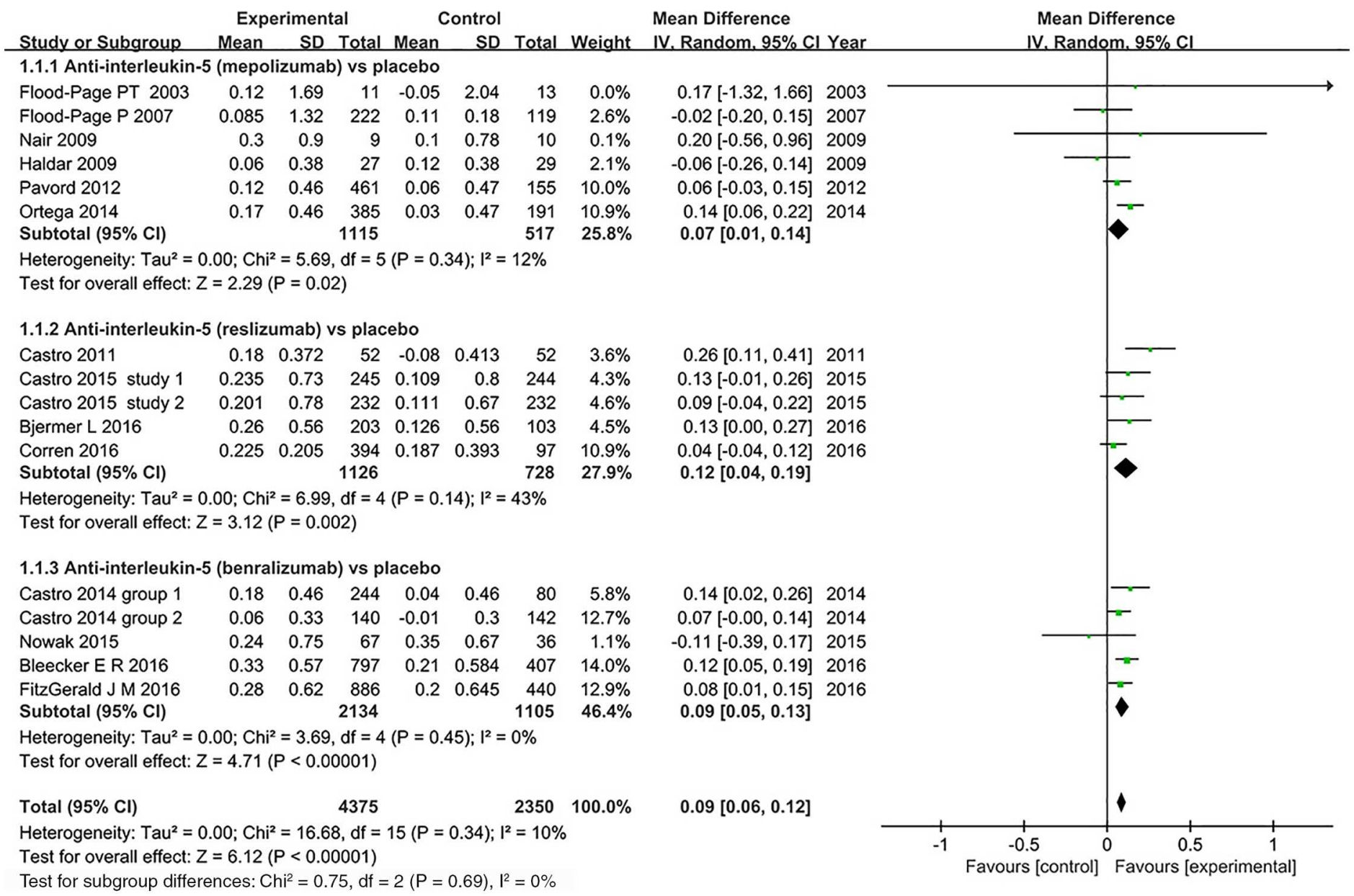

Fig 2. The effect of anti-interleukin 5 versus placebo on $\mathrm{FEV}_{\mathbf{1}} . \mathrm{Cl}=$ confidence interval; $\mathrm{FEV} \mathrm{V}_{1}=$ forced expiratory volume in 1 second; $\mathrm{SD}=$ standard derivation; IV = Inverse Variance.

doi:10.1371/journal.pone.0166833.g002

Adverse events. 13 studies reported adverse events, and anti-interleukin 5 therapy was well tolerated [23-26,28-33,35-37]. The pooled RR was 0.93 (95\% CI: 0.89-0.98), which showed the lower adverse events incidence were slightly in the anti-interleukin 5 group $(P=0.002)$, with modest heterogeneity $\left(I^{2}=46 \%, P=0.02,95 \%\right.$ CI $2.3 \%$ to $\left.71 \%, H_{M}^{2}=0.87\right)$ (Fig 9). However, sensitivity analysis that excluded two studies which included patients with non-eosinophilic asthma revealed no heterogeneity $\left(I^{2}=0 \%, P=0.75,95 \%\right.$ CI $0 \%$ to $48 \%$, $\left.H_{M}^{2}=-0.3\right)[30,33]$. Therefore, the heterogeneity can be explained by the varied participant types. In subgroup analysis, however, only treatment with reslizumab was associated with a trend of lower adverse events incidence ( $\mathrm{RR}=0.88,95 \% \mathrm{CI}: 0.81-0.96, P=0.003)$, while no significant differences were found in both mepolizumab $(\mathrm{RR}=0.95,95 \% \mathrm{CI}: 0.89-1.01$, $P=0.12)$ and benralizumab treatment groups ( $\mathrm{RR}=0.98,95 \% \mathrm{CI}: 0.92-1.04 P=0.44)$.

\section{Risk of bias}

Fig 10 summarizes the methodological domain assessments for each included study. Most trials had low risk of bias across the six domains. The allocation sequence was adequately generated and concealed in fourteen trials, [22-29,32-37]. The randomization techniques included 


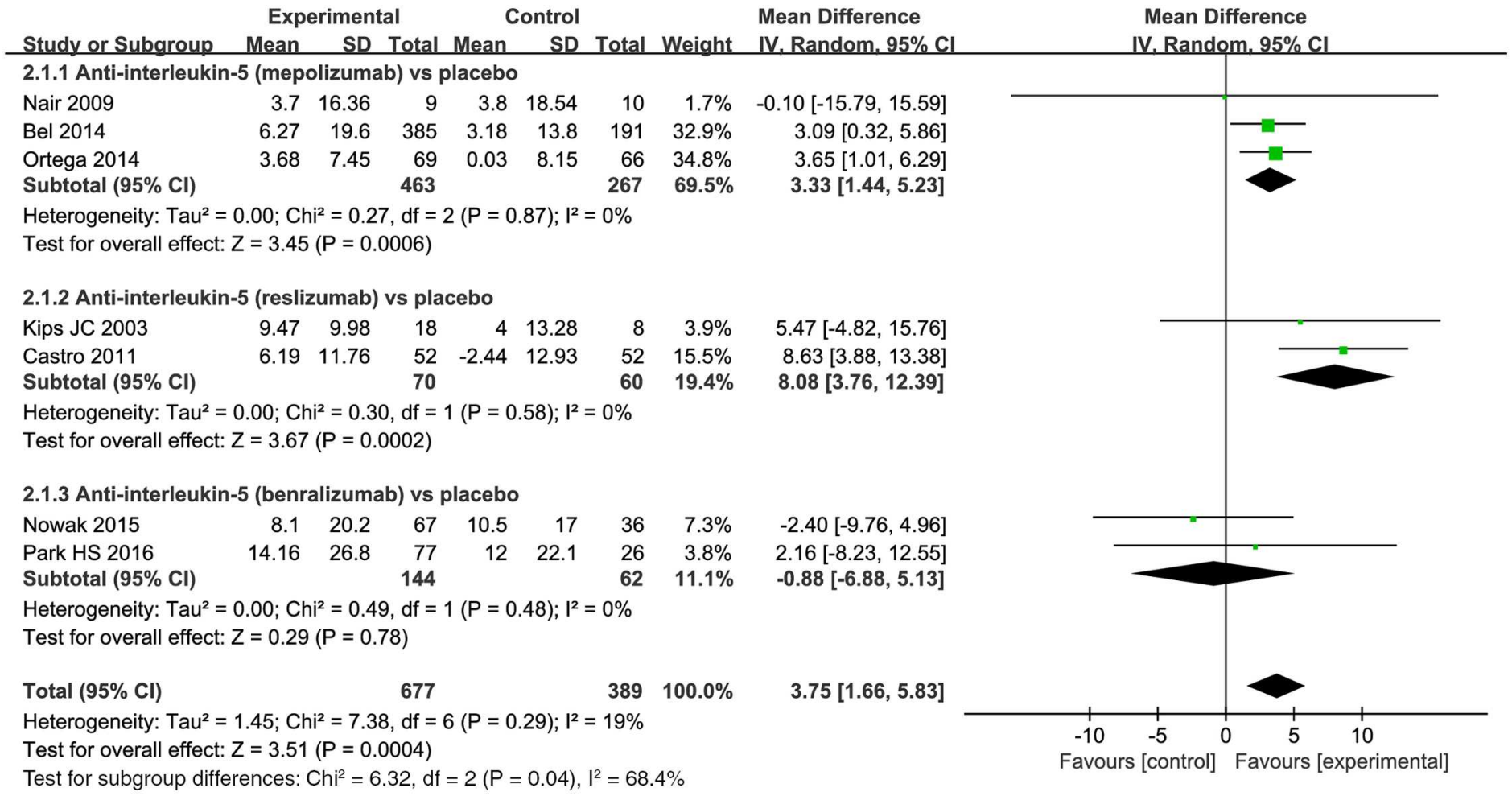

Fig 3. The effect of anti-interleukin 5 versus placebo on $\mathrm{FEV}_{1} \%$ of predicted value.

doi:10.1371/journal.pone.0166833.g003

computer generated randomization codes and minimization. The remaining trials did not report the method used, and we were unable to obtain this information. All but one study was described as double-blinded [20]. Almost all RCTs reported complete outcome data, only one trial reported on attrition insufficiently [27].

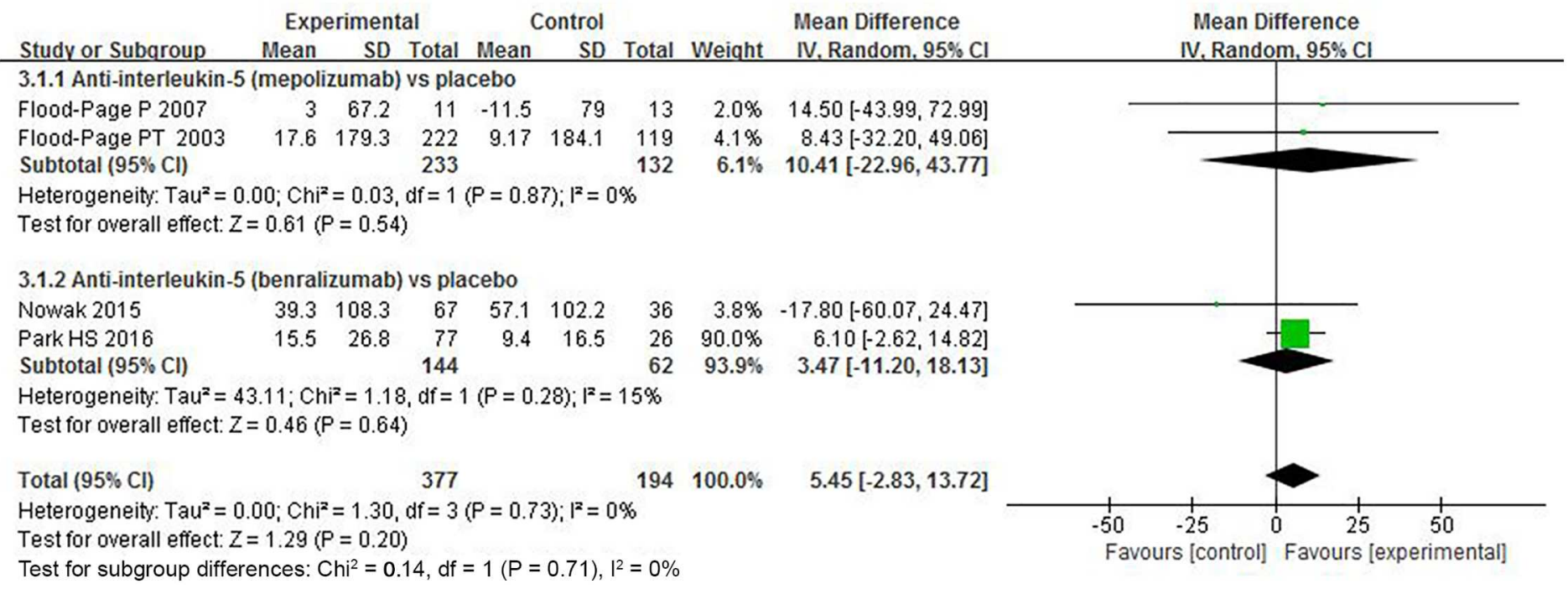

Fig 4. The effects of anti-interleukin-5 on PEF (L/min).

doi:10.1371/journal.pone.0166833.g004 


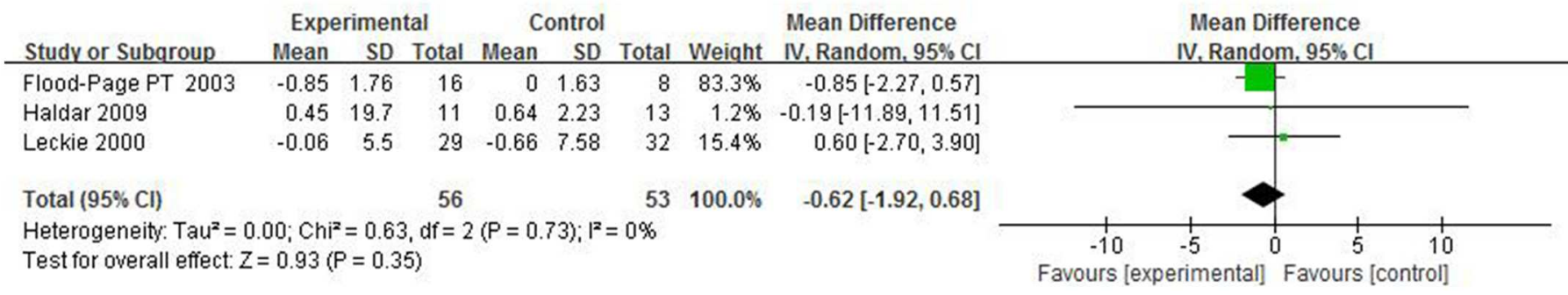

Fig 5. The effects of anti-interleukin-5 on histamine $\mathrm{PC}_{20}(\mathrm{mg} / \mathrm{ml})$. doi:10.1371/journal.pone.0166833.g005

\section{Subgroup analyses and sensitivity analysis}

To clarify the heterogeneity or identify the optimal patients for this treatment, subgroup analyses were carried out for asthma exacerbations and $\mathrm{FEV}_{1}$ (Table 5). The studies were stratified according to effects model, asthma severity, asthma types, sample size, drug administration dosage, follow-up duration and published year. Subgroup analyses showed the efficacy of antiinterleukin 5 on asthma exacerbations were only influenced by asthma severity. Most subgroups showed significantly reduced exacerbations risk. Single dose anti-interleukin 5 in two studies showed no significant differences in exacerbation rates. However, the subgroup results should be interpreted with caution because of the limited sample size and potential bias inherent to subgroup analysis. The meta-analysis findings remained stable with multicenter trials. In addition, excluding the results of any single study did not alter the overall findings.

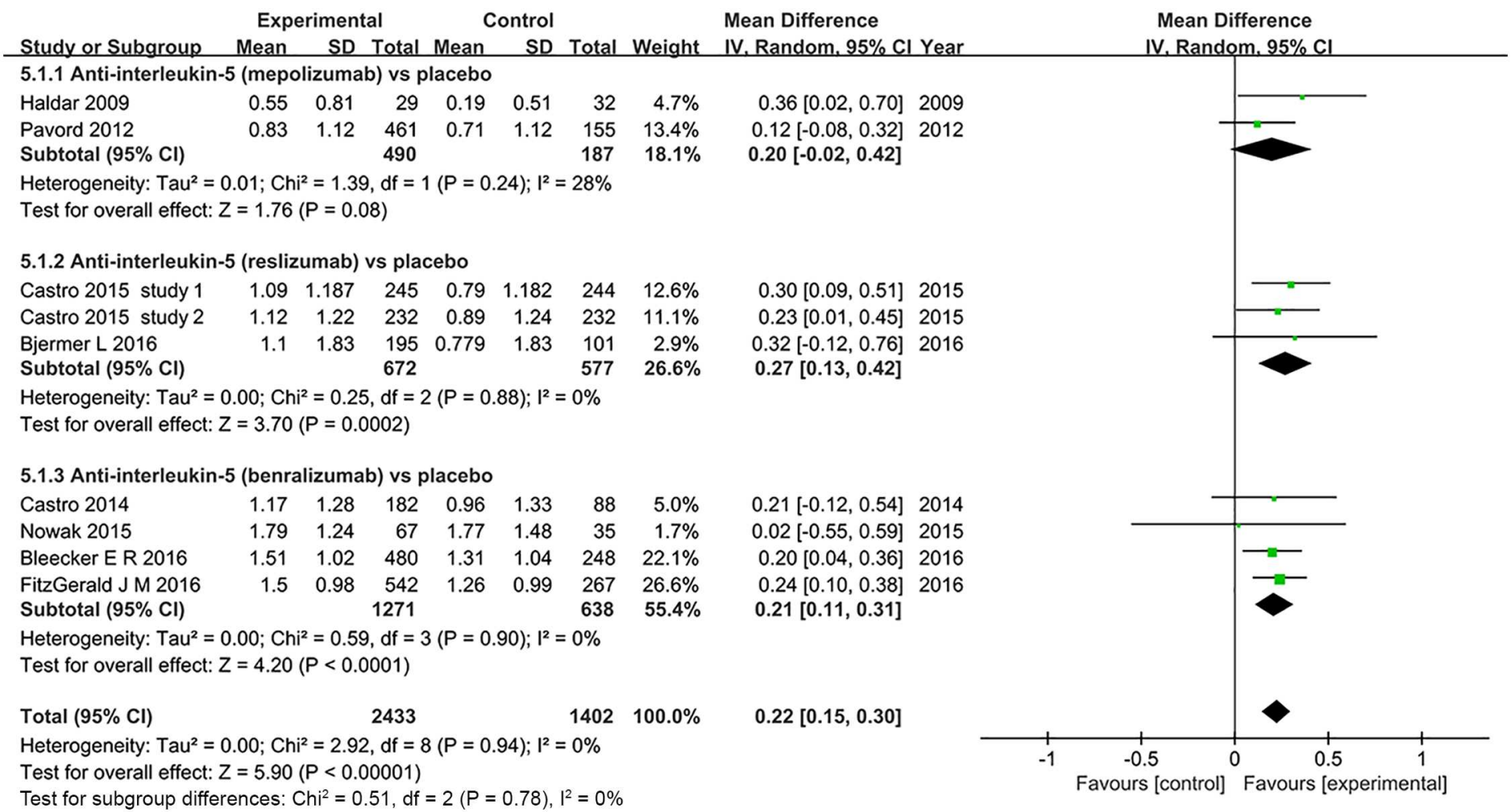

Fig 6. The effects of anti-interleukin 5 on Asthma Quality of Life Questionnaire (AQLQ). doi:10.1371/journal.pone.0166833.g006 


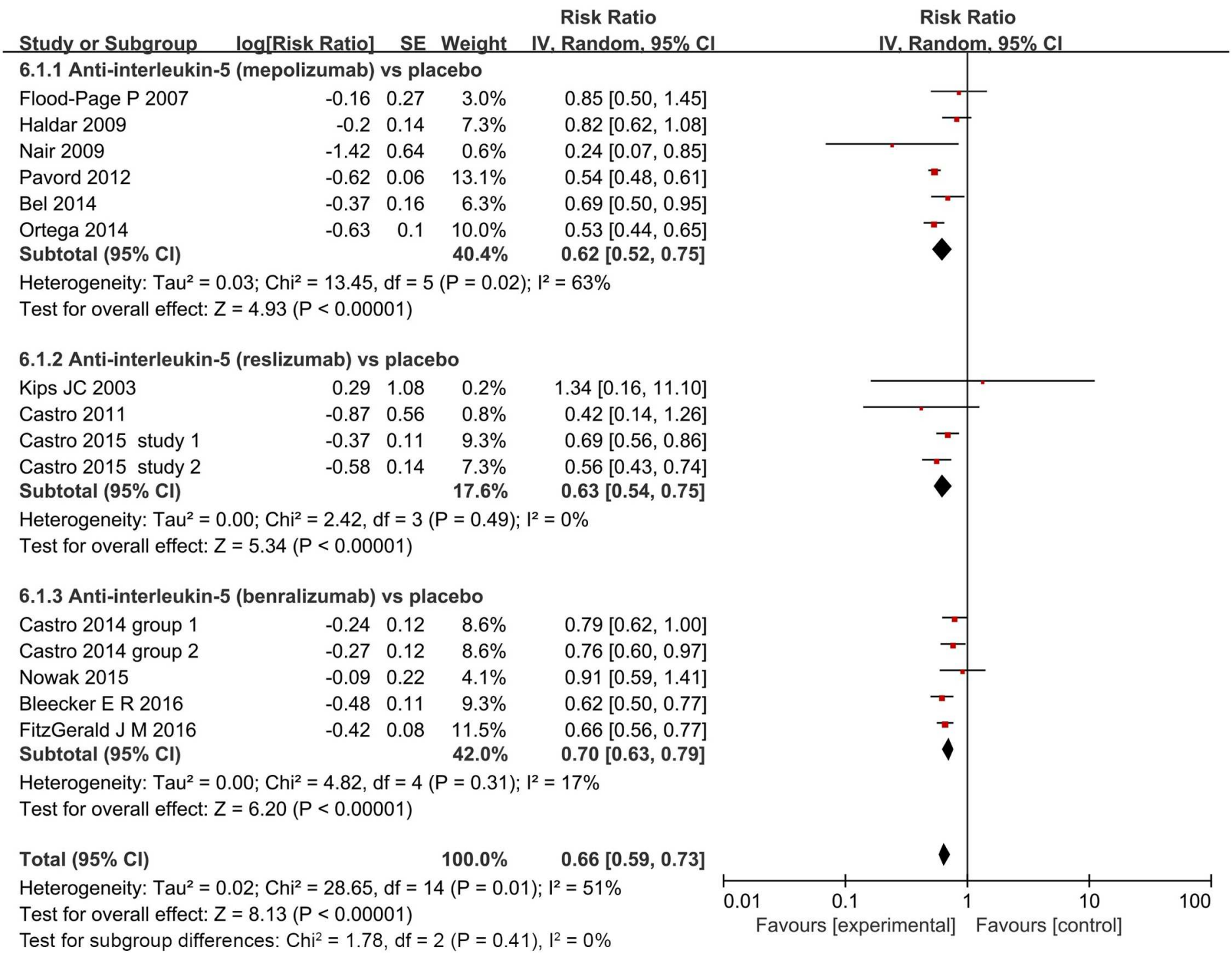

Fig 7. The effect of anti-interleukin 5 versus placebo on exacerbation. IV = Inverse Variance.

doi:10.1371/journal.pone.0166833.g007

Furthermore, based on the subgroups analysis, we could know that anti-interleukin 5 can significantly improve the $\mathrm{FEV}_{1}$ of severe asthma $(\mathrm{MD}=0.11, P<0.001)$ and eosinophilic asthma $(\mathrm{MD}=0.11, P=0.001)$. This further confirmed that the severe eosinophilic asthma patients are the optimal patients for anti-interleukin 5 treatment.

\section{Publication bias}

Publication bias was assessed using Begg's funnel plot and Egger's test. Begg's funnel plot of the 14 studies evaluated the effect of anti-interleukin 5 on FEV1 and the Egger's test suggested no publication bias $(P=0.78$, Fig 11$)$. And also no publication bias was detected by Egger's test for other outcomes analysis (all $P>0.05$ ). However, we could not fully exclude publication bias in four outcomes ( $\mathrm{FEV}_{1} \%, \mathrm{PEF}$, histamine PC20, SABA rescue use); we could not evaluate the potential risk of publication bias, since these tests have very low power in meta-analysis. 


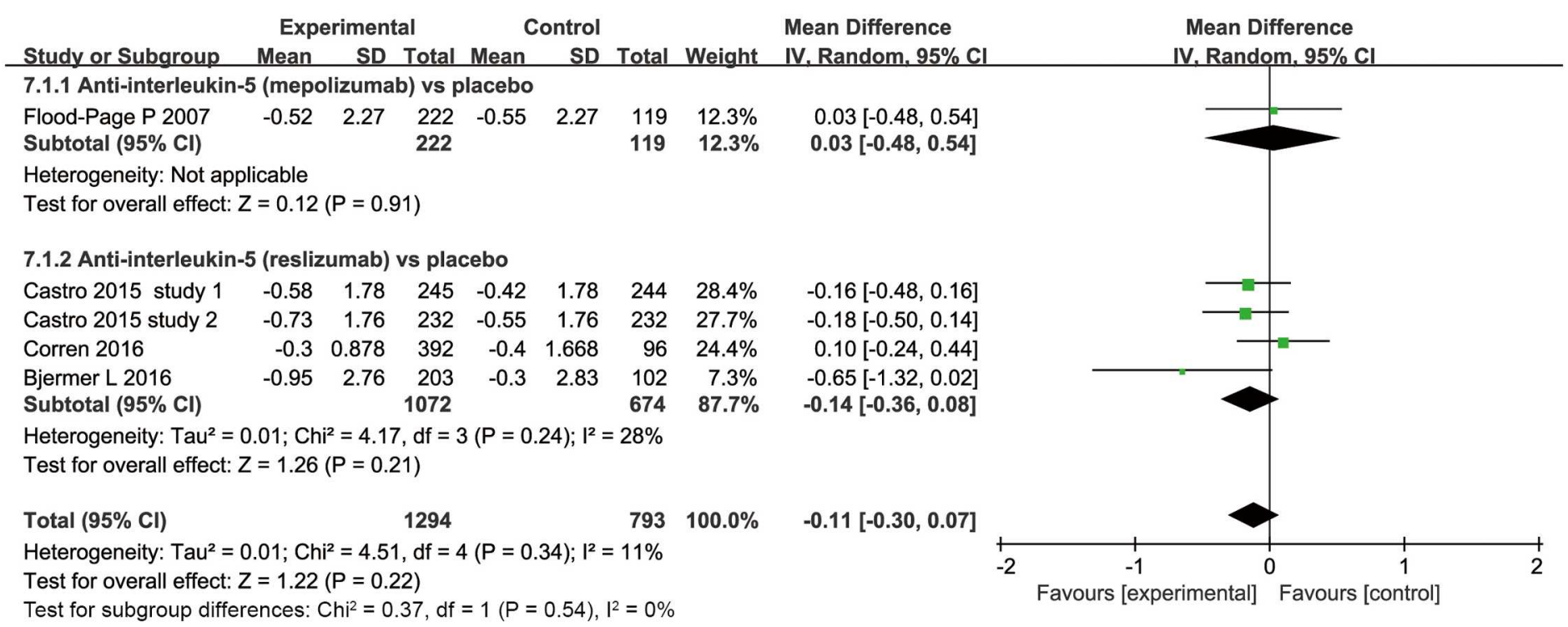

Fig 8. The effects of anti-interleukin-5 on SABA rescue use.

doi:10.1371/journal.pone.0166833.g008

\section{Discussion}

We identified 20 RCTs investigating the effect of anti-interleukin 5 monoclonal antibodies in patients with asthma. The results suggest that anti-interleukin 5 therapy was well tolerated and could significantly improve AQLQ score, $\mathrm{FEV}_{1}, \mathrm{FEV}_{1} \%$ of predicted value, and decrease asthmatic exacerbation, blood and sputum eosinophil levels, but yielded no effects in $\mathrm{PEF}, \mathrm{PC}_{20}$, SABA rescue use. Additionally, reslizumab seems to be safer and more effective than the other two drugs based on all outcomes. However, since varied baseline of patients among studies, it is not possible to draw a firm conclusion. Different from previous systematic reviews that only included studies of on mepolizumab [38, 39], we included trials about mepolizumab and other two anti-interleukin-5 antibodies-reslizumab and benralizumab. Additionally, the results should be interpreted with caution due to with the relatively small sample sizes and small number of included trials. Therefore, our results may be more believable. In contrast to previous systematic reviews, we found that anti-interleukin-5 treatment slightly increased $\mathrm{FEV}_{1}$ and $\mathrm{FEV}_{1} \%$ of predicted value. But the clinical relevance of this finding to patients may not be clinically important because of the modest improvement. Only three or four studies reported detailed data, therefore we could not draw exact conclusions for these two parameters due to the insufficient data. Previous two systematic reviews failed to show a significant effect in $\mathrm{FEV}_{1}$, likely due to small number of trials analyzed [38, 39]. Liu et al [39] converted and pooled continuous variable data such as blood and sputum eosinophils. To reduce the possible bias resulting from data conversion, we only obtained qualitative descriptions with estimations of the two outcomes. Besides, when studies with multiple intervention groups, Liu et al [39] only selected one pair of interventions and exclude the others which are not generally recommended by Cochrane handbook. Our meta-analysis found that there was a significant improvement in AQLQ score, which is consistent with previous two meta-analyses. However, as the mean change in AQLQ score is less than the clinical minimally important difference of 0.5 units, the clinical relevance of this finding may not be clinically important to patients [40]. Asthma exacerbations are associated with substantial morbidity and mortality [41]. Decreasing the asthma exacerbations rate is a key goal in asthma management. Our meta-analysis showed 


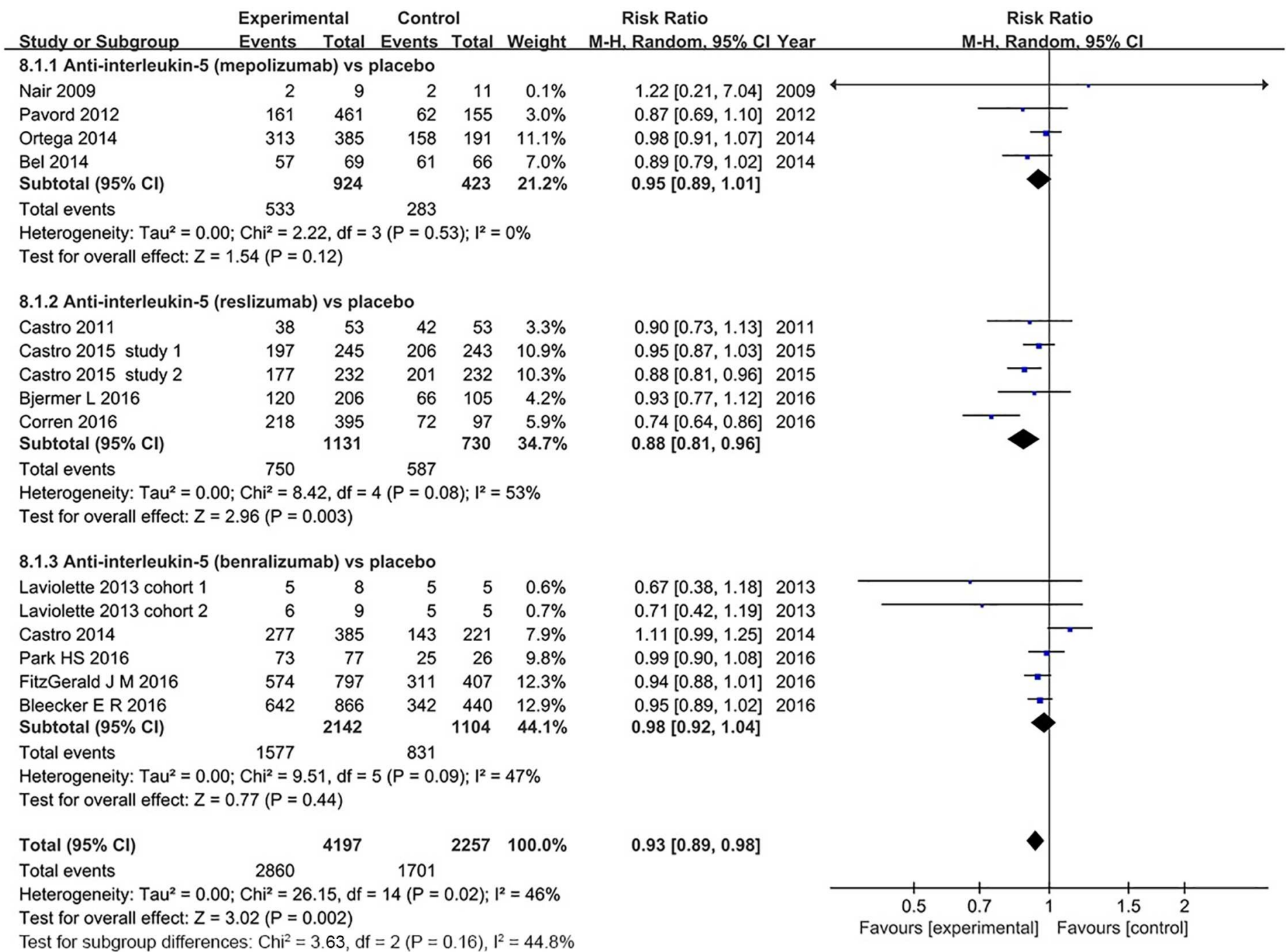

Fig 9. The effect of anti-interleukin 5 versus placebo on adverse events.

doi:10.1371/journal.pone.0166833.g009

a significant reduction in exacerbation rates. The clinical relevance of this finding to patients may be clinically important. The inconsistency of the results between asthma exacerbations and rescue use of SABA might due to the next two reasons: 1) the slight improvement in lung functions; 2) most exacerbations in trials were predominantly those that would generally be judged severe on the basis of a need for systemic corticosteroid or requiring admission or visit to emergency. This systematic review also has limitations. First, we aimed to identify the overall effect of anti-interleukin-5 therapy on asthma, the asthma severity and baseline asthma therapy varied among studies (Table 2), so the population examined in this review was too heterogeneous to draw any conclusions about the general asthma population. Further research is needed to clarify which subgroups of patients with asthma can benefit from this treatment. Second, in accordance with the Cochrane handbook, we combined two or three intervention groups into a single intervention group regardless of different intervention dosage and administration routine. This made identifying the optimal dose and regimen for treating asthma difficult. Thirdly, although these studies shared many common issues, there were also substantial 


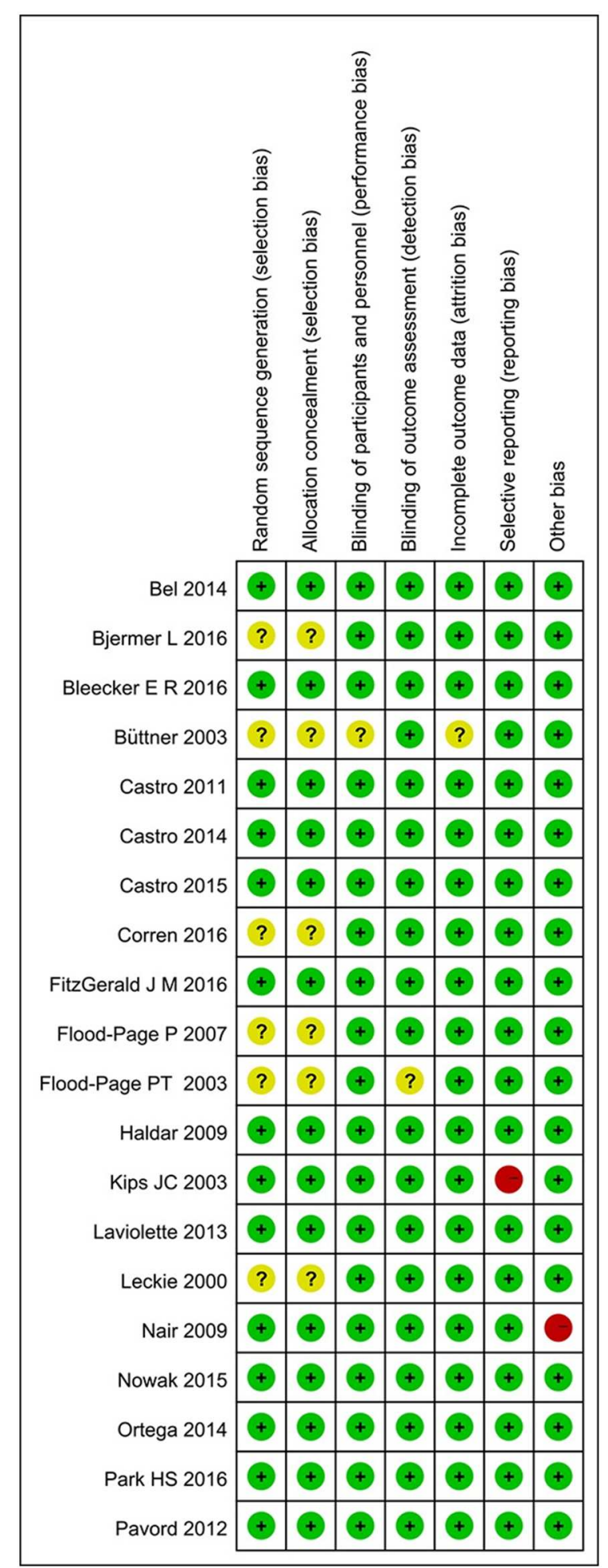

Fig 10. Risk of bias summary.

doi:10.1371/journal.pone.0166833.g010 
Table 5. Subgroup analysis and sensitivity analyses of asthma exacerbation and FEV $\mathrm{V}_{\mathbf{1}}$ in RCTs.

\begin{tabular}{|c|c|c|c|c|c|c|c|c|}
\hline \multirow[t]{2}{*}{ Stratification } & \multicolumn{4}{|c|}{ asthma exacerbation } & \multicolumn{4}{|l|}{ FEV $_{1}$} \\
\hline & \begin{tabular}{|l|}
$\begin{array}{l}\text { No. of Patients } \\
\text { (Studies) }\end{array}$ \\
\end{tabular} & $\mathrm{RR}(95 \% \mathrm{Cl})$ & $P$ Value & $r^{2}, \%$ & $\begin{array}{l}\text { No. of Patients } \\
\text { (Studies) }\end{array}$ & MD(95\% Cl) & $P$ Value & $I^{2}, \%$ \\
\hline \multicolumn{9}{|l|}{ Subgroup analysis } \\
\hline \multicolumn{9}{|l|}{ Effects model } \\
\hline random-effects model & $6072(13)$ & $0.66(0.59-0.73)$ & $<0.001$ & 51 & $6725(14)$ & $0.09(0.06-0.12)$ & $<0.001$ & 10 \\
\hline fixed effects model & $6072(13)$ & $0.63(0.59-0.67)$ & $<0.001$ & 51 & $6725(14)$ & $0.09(0.06-0.12)$ & $<0.001$ & 10 \\
\hline \multicolumn{9}{|l|}{ Asthma severity } \\
\hline $\begin{array}{l}\text { mild or moderate } \\
\text { asthma }\end{array}$ & $362(1)$ & $0.85(0.51-1.43)$ & 0.55 & $\ldots$ & $365(2)$ & $-0.02(-0.2-0.15)$ & 0.8 & 0 \\
\hline severe asthma & $4090(8)$ & $0.59(0.53-0.65)$ & $<0.001$ & 23 & $3901(7)$ & $0.11(0.07-0.14)$ & $<0.001$ & 35 \\
\hline mixed asthma & $1620(4)$ & $0.73(0.65-0.82)$ & $<0.001$ & 18 & $2459(5)$ & $0.08(0.04-0.12)$ & $<0.001$ & 0 \\
\hline \multicolumn{9}{|l|}{ Asthma types } \\
\hline eosinophilic asthma & $3117(7)^{*}$ & $0.64(0.56-0.74)$ & $<0.001$ & 65 & $3002(6)^{*}$ & $0.11(0.05-0.17)$ & $<0.001$ & 46 \\
\hline $\begin{array}{l}\text { mon-eosinophilic } \\
\text { asthma }\end{array}$ & 282(1) & $0.76(0.60-0.97)$ & 0.02 & $\ldots$ & $773(2)$ & $0.06(0.00-0.11)$ & 0.05 & 0 \\
\hline mixed asthma & $2673(6)$ & $0.66(0.57-0.77)$ & $<0.001$ & 24 & $2950(7)$ & $0.10(0.05-0.15)$ & $<0.001$ & 0 \\
\hline \multicolumn{9}{|l|}{ No. of subjects } \\
\hline$<100$ & $107(3)$ & $0.63(0.28-1.45)$ & 0.28 & 46 & $99(3)$ & $-0.04(-0.23-0.15)$ & 0.68 & 0 \\
\hline$\geq 100$ & $5965(10)$ & $0.65(0.59-0.72)$ & $<0.001$ & 51 & $6626(11)$ & $0.09(0.06-0.13)$ & $<0.001$ & 16 \\
\hline \multicolumn{9}{|l|}{ Follow-up } \\
\hline$<50$ weeks & $2530(8)$ & $0.64(0.54-0.76)$ & $<0.001$ & 33 & $3168(9)$ & $0.10(0.05-0.16)$ & $<0.001$ & 34 \\
\hline$\geq 50$ weeks & $3542(5)$ & $0.67(0.59-0.76)$ & $<0.001$ & 67 & $3557(5)$ & $0.08(0.04-0.12)$ & $<0.001$ & 0 \\
\hline \multicolumn{9}{|l|}{ Intervention dosage } \\
\hline single dose & 134(2) & $0.93(0.61-1.42)$ & 0.73 & 0 & 103(1) & $-0.11(-0.39-0.17)$ & 0.45 & $\ldots$ \\
\hline multiple doses & $5938(11)$ & $0.65(0.57-0.74)$ & $<0.001$ & 58 & $6622(13)$ & $0.09(0.07-0.12)$ & $<0.001$ & 5 \\
\hline \multicolumn{9}{|l|}{ Year } \\
\hline published year $\leq 2011$ & $575(5)$ & $0.73(0.52-1.02)$ & 0.07 & 21 & $544(5)$ & $0.08(-0.01-0.25)$ & 0.4 & 54 \\
\hline published year >2011 & $5497(8)$ & $0.64(0.58-0.71)$ & $<0.001$ & 56 & 6181(9) & $0.09(0.06-0.12)$ & $<0.001$ & 0 \\
\hline \multicolumn{9}{|l|}{ Sensitivity analysis } \\
\hline Non-multicenter & 5991(11) & $0.65(0.59-0.72)$ & $<0.001$ & 47 & 6626(11) & $0.09(0.06-0.13)$ & $<0.001$ & 16 \\
\hline One-study-out method & $\ldots$ & $\ldots$ & $\begin{array}{c}\text { From } 0.65(0.58- \\
0.71) \text { to } 0.68 \\
(0.61-0.75)\end{array}$ & $\ldots$ & & $\cdots$ & & \\
\hline
\end{tabular}

*The Castro 2015 inclued two groups, group 1 for eosinophilic asthma, group 2 for non-eosinophilic asthma.

doi:10.1371/journal.pone.0166833.t005

subgroup and study heterogeneities. Moreover, there also was significant heterogeneity among studies evaluating asthma exacerbation and adverse events; although we used a random-effects model to account for this, the correction is only partial. As for PEF, histamine PC20 and SABA rescue use, given the small number of studies being meta-analysed, it is difficult to detect heterogeneity and accurately estimate it [42]. Lastly, Ortega et al [43] re-examined baseline blood eosinophil counts from previous two studies $[24,26]$ on mepolizumab, they found that the use of the baseline at a threshold of at least 150 cells $/ \mu \mathrm{L}$ can be a reliable and simple biomarker for patient selection associated with positive clinical responses to mepolizumab treatment. However, due to the lack of individual patient data among all studies, we failed to further analysis the relationship between blood eosinophil counts $\geq 150$ cells $/ \mu \mathrm{L}$ at baseline and outcomes of mepolizumab, reslizumab and benralizumab treatment. 


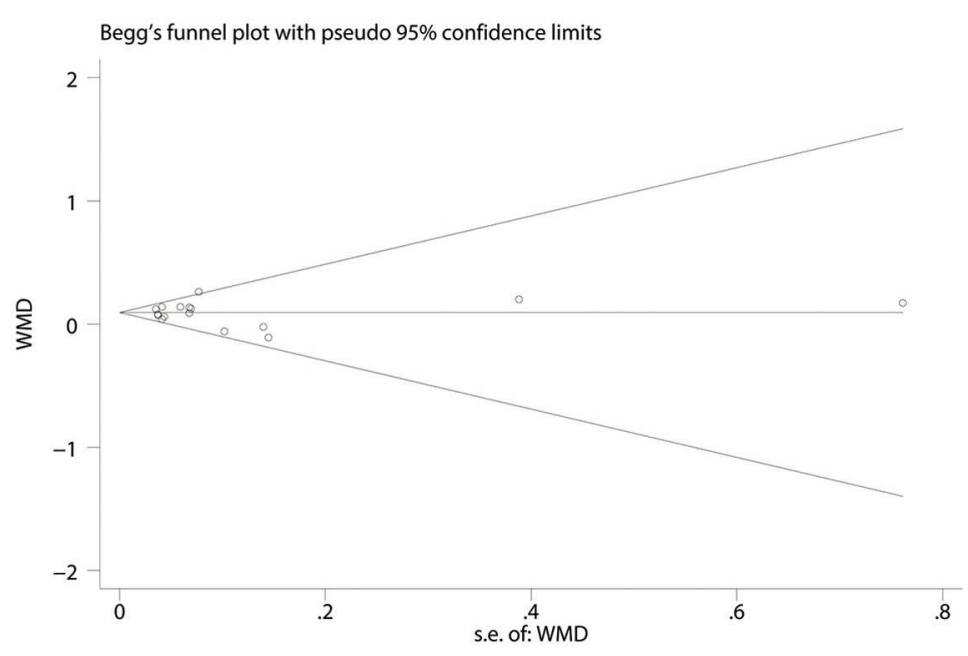

Fig 11. Begg's funnel plot evaluated the effect of anti-interleukin-5 on FEV . $^{\text {. }}$

doi:10.1371/journal.pone.0166833.g011

\section{Conclusions}

Our study indicates that anti-interleukin-5 therapy is safe and may reduce asthma exacerbation risk, slightly improve $\mathrm{FEV}_{1}, \mathrm{FEV}_{1} \%$, and quality of life; and decrease blood and sputum eosinophil levels, although $\mathrm{PEF}, \mathrm{PC}_{20}$ were not improved or SABA rescue use reduced. Antiinterleukin-5 therapy may therefore be beneficial as adjunct asthma therapy, particularly in severe and eosinophilic asthma. Further trials are necessary to determine the most effective asthma treatment drug and studies need to be performed that distinguish which patients will respond to particular antibodies, both within and between classes (i.e., who will respond to mepolizumab vs. benralizumab or? reslizumab vs. benralizumab?).

\section{Supporting Information}

S1 Table. Search strategies.

(DOCX)

S2 Table. Secondary efficacy outcomes of included RCTs.

(DOCX)

S3 Table. The data of all outcomes in all RCTs.

(DOCX)

S4 Table. PRISMA 2009 Checklist.

(DOCX)

\section{Author Contributions}

Conceptualization: HM.

Data curation: FPW TL.

Formal analysis: FPW TL ZL SYL.

Investigation: FPW TL.

Methodology: HM. 
Project administration: HM.

Resources: HM.

Software: FPW TL.

Supervision: HM.

Validation: FPW TL.

Visualization: FPW TL.

Writing - original draft: FPW TL.

Writing - review \& editing: HM ZL SYL.

\section{References}

1. The Global Asthma Report 2014. Auckland, New Zealand: Global Asthma Network, 2014. Available: http://www.globalasthmareport.org/resources/Global_Asthma_Report_2014.pdf.

2. Bateman ED, Hurd SS, Barnes PJ, Bousquet J, Drazen JM, FitzGerald M, et al. Global strategy for asthma management and prevention: GINA executive summary. Eur Respir J. 2008; 31(1):143-78. doi: 10.1183/09031936.00138707 PMID: 18166595.

3. Masoli M, Fabian D, Holt S, Beasley R, Global Initiative for Asthma P. The global burden of asthma: executive summary of the GINA Dissemination Committee report. Allergy. 2004; 59(5):469-78. doi: 10. 1111/j.1398-9995.2004.00526.x PMID: 15080825.

4. Mclvor RA. Emerging therapeutic options for the treatment of patients with symptomatic asthma. Ann Allergy Asthma Immunol. 2015; 115(4):265-71.e5. doi: 10.1016/j.anai.2015.07.011

5. Torrego A, Sola I, Munoz AM, Roque IFM, Yepes-Nunez JJ, Alonso-Coello P, et al. Bronchial thermoplasty for moderate or severe persistent asthma in adults. Cochrane Database Syst Rev. 2014;(3: ): CD009910. doi: 10.1002/14651858.CD009910.pub2 PMID: 24585221.

6. Chung KF. Targeting the interleukin pathway in the treatment of asthma. The Lancet. 2015; 386 (9998):1086-96. doi: 10.1016/S0140-6736(15)00157-9

7. Mitchell PD, El-Gammal Al, O'Byrne PM. Emerging monoclonal antibodies as targeted innovative therapeutic approaches to asthma. Clin Pharmacol Ther. 2016; 99(1):38-48. doi: 10.1002/cpt.284

8. Cardet JC, Israel E. Update on reslizumab for eosinophilic asthma. Expert Opin Biol Ther. 2015; 15 (10):1531-9. doi: 10.1517/14712598.2015.1090972

9. Yamaguchi Y, Suda T, Suda J, Eguchi M, Miura Y, Harada N, et al. Purified interleukin 5 supports the terminal differentiation and proliferation of murine eosinophilic precursors. J Exp Med. 1988; 167(1):4356. PMID: 3257253

10. Garcia G, Taille C, Laveneziana P, Bourdin A, Chanez P, Humbert M. Anti-interleukin- 5 therapy in severe asthma. Eur Respir Rev. 2013; 22(129):251-7. doi: 10.1183/09059180.00004013

11. Takatsu K, Nakajima H. IL-5 and eosinophilia. Curr Opin Immunol. 2008; 20(3):288-94. doi: 10.1016/j. coi.2008.04.001

12. Patterson MF, Borish L, Kennedy JL. The past, present, and future of monoclonal antibodies to IL-5 and eosinophilic asthma: A review. J Asthma Allergy. 2015; 8:125-34. doi: 10.2147/JAA.S74178

13. Durham AL, Caramori G, Chung KF, Adcock IM. Targeted anti-inflammatory therapeutics in asthma and chronic obstructive lung disease. TransI Res. 2016; 167(1):192-203. doi: 10.1016/j.trsl.2015.08. 004

14. Higgins J. Green S. Cochrane handbook for systematic reviews of interventions version 5.1. 0. The Cochrane Collaboration, 2011. 2013.

15. Mittlbock $\mathrm{M}$, Heinzl $\mathrm{H}$. A simulation study comparing properties of heterogeneity measures in metaanalyses. Stat Med. 2006; 25(24):4321-33. doi: 10.1002/sim.2692 PMID: 16991104.

16. Ioannidis JP, Patsopoulos NA, Evangelou E. Uncertainty in heterogeneity estimates in meta-analyses. BMJ (Clinical researched). 2007; 335(7626):914-6. doi: 10.1136/bmj.39343.408449.80 PMID: 17974687; PubMed Central PMCID: PMC2048840.

17. Higgins JP, Thompson SG. Quantifying heterogeneity in a meta-analysis. Stat Med. 2002; 21 (11):1539-58. doi: 10.1002/sim.1186 PMID: 12111919. 
18. Leckie MJ, Ten Brinke A, Khan J, Diamant Z, O'Connor BJ, Walls CM, et al. Effects of an interleukin-5 blocking monoclonal antibody on eosinophils, airway hyper-responsiveness, and the late asthmatic response. The Lancet. 2000; 356(9248.):2144-8. doi: 10.1016/S0140-6736(00)03496-6

19. Flood-Page P, Menzies-Gow A, Phipps S, Ying S, Wangoo A, Ludwig MS, et al. Anti-IL-5 treatment reduces deposition of ECM proteins in the bronchial subepithelial basement membrane of mild atopic asthmatics. Am J Respir Crit Care Med. 2003; 112(7):1029-36. doi: 10.1172/JCI17974 PMID: 14523040.

20. Büttner C, Lun A, Splettstoesser T, Kunkel G, Renz H. Monoclonal anti-interleukin- 5 treatment suppresses eosinophil but not T-cell functions. Eur Respir J. 2003; 21(5):799-803. doi: 10.1183/ 09031936.03 .00027302

21. Flood-Page $P$, Swenson $C$, Faiferman I, Matthews J, Williams M, Brannick L, et al. A study to evaluate safety and efficacy of mepolizumab in patients with moderate persistent asthma. Am J Respir Crit Care Med. 2007; 176(11):1062-71. doi: 10.1164/rccm.200701-085OC

22. Haldar P, Brightling CE, Hargadon B, Gupta S, Monteiro W, Sousa A, et al. Mepolizumab and exacerbations of refractory eosinophilic asthma. N Engl J Med. 2009; 360(10):973-84. doi: 10.1056/ NEJMoa0808991

23. Nair P, Pizzichini MMM, Kjarsgaard M, Inman MD, Efthimiadis A, Pizzichini E, et al. Mepolizumab for prednisone-dependent asthma with sputum eosinophilia. N Engl J Med. 2009; 360(10):985-93. doi: 10. 1056/NEJMoa0805435

24. Pavord ID, Korn S, Howarth P, Bleecker ER, Buhl R, Keene ON, et al. Mepolizumab for severe eosinophilic asthma (DREAM): A multicentre, double-blind, placebo-controlled trial. The Lancet. 2012; 380 (9842):651-9. doi: 10.1016/S0140-6736(12)60988-X

25. Bel EH, Wenzel SE, Thompson PJ, Prazma CM, Keene ON, Yancey SW, et al. Oral glucocorticoidsparing effect of mepolizumab in eosinophilic asthma. N Engl J Med. 2014; 371(13):1189-97. doi: 10. 1056/NEJMoa1403291

26. Ortega HG, Liu MC, Pavord ID, Brusselle GG, FitzGerald JM, Chetta A, et al. Mepolizumab treatment in patients with severe eosinophilic asthma. N Engl J Med. 2014; 371(13):1198-207. doi: 10.1056/ NEJMoa1403290 PMID: 25199059.

27. Kips JC, O'Connor BJ, Langley SJ, Woodcock A, Kerstjens HA, Postma DS, et al. Effect of SCH55700, a humanized anti-human interleukin- 5 antibody, in severe persistent asthma: a pilot study. Am J Respir Crit Care Med. 2003; 167(12):1655-9. Epub 2003/03/22. doi: 10.1164/rccm.200206-525OC PMID: 12649124.

28. Castro M, Mathur S, Hargreave F, Boulet LP, Xie F, Young J, et al. Reslizumab for poorly controlled, eosinophilic asthma: a randomized, placebo-controlled study. Am J Respir Crit Care Med. 2011; 184 (10):1125-32. Epub 2011/08/20. doi: 10.1164/rccm.201103-0396OC PMID: 21852542.

29. Castro M, Zangrilli J, Wechsler ME, Bateman ED, Brusselle GG, Bardin P. Reslizumab for inadequately controlled asthma with elevated blood eosinophil counts: results from two multicentre, parallel, doubleblind, randomised, placebo-controlled, phase 3 trials. Lancet Respir Med. 2015; 3(5):355-66. doi: 10. 1016/S2213-2600(15)00042-9 PMID: 25736990

30. Corren J, Weinstein S, Janka L, Zangrilli J, Garin M. Phase 3 Study of Reslizumab in Patients with Poorly Controlled Asthma: Effects Across a Broad Range of Eosinophil Counts. Chest. 2016; 45715-6. doi: 10.1016/j.chest.2016.03.018 PMID: 27018175.

31. Bjermer L, Lemiere C, Maspero J, Weiss S, Zangrilli J, Germinaro M. Reslizumab for Inadequately Controlled Asthma with Elevated Blood Eosinophil Levels: a Randomized Phase 3 Study. Chest. 2016; 47551-3. doi: 10.1016/j.chest.2016.03.032 PMID: 27056586.

32. Laviolette M, Gossage DL, Gauvreau G, Leigh R, Olivenstein R, Katial R, et al. Effects of benralizumab on airway eosinophils in asthmatic patients with sputum eosinophilia. J Allergy Clin Immunol. 2013; 132 (5):1086-96.e5. doi: 10.1016/j.jaci.2013.05.020

33. Castro M, Wenzel SE, Bleecker ER, Pizzichini E, Kuna P, Busse WW, et al. Benralizumab, an anti-interleukin 5 receptor alpha monoclonal antibody, versus placebo for uncontrolled eosinophilic asthma: A phase $2 b$ randomised dose-ranging study. Lancet Respir Med. 2014; 2(11):878-90. doi: 10.1016/ S2213-2600(14)70201-2 PMID: 25306557.

34. Nowak RM, Parker JM, Silverman RA, Rowe BH, Smithline H, Khan F. A randomized trial of benralizumab, an antiinterleukin 5 receptor alpha monoclonal antibody, after acute asthma. Am J Emerg Med. 2015; 33(1):14-20. doi: 10.1016/j.ajem.2014.09.036 PMID: 25445859.

35. Park HS, Kim MK, Imai N, Nakanishi T, Adachi M, Ohta K, et al. A phase 2a study of benralizumab for patients with eosinophilic asthma in South Korea and Japan. Int Arch Allergy Immunol. 2016; 169 (3):135-45. doi: 10.1159/000444799

36. Bleecker ER, FitzGerald JM, Chanez P, Papi A, Weinstein SF, Barker P, et al. Efficacy and safety of benralizumab for patients with severe asthma uncontrolled with high-dosage inhaled corticosteroids 
and long-acting beta2-agonists (SIROCCO): a randomised, multicentre, placebo-controlled phase 3 trial. Lancet. 2016. doi: 10.1016/S0140-6736(16)31324-1 PMID: 27609408.

37. FitzGerald JM, Bleecker ER, Nair P, Korn S, Ohta K, Lommatzsch M, et al. Benralizumab, an anti-interleukin-5 receptor alpha monoclonal antibody, as add-on treatment for patients with severe, uncontrolled, eosinophilic asthma (CALIMA): a randomised, double-blind, placebo-controlled phase 3 trial. Lancet. 2016. doi: 10.1016/S0140-6736(16)31322-8 PMID: 27609406.

38. Powell C, Milan SJ, Dwan K, Bax L, Walters N. Mepolizumab versus placebo for asthma. Cochrane Database Syst Rev. 2015;7: :CD010834. doi: 10.1002/14651858.CD010834.pub2 PMID: 26214266.

39. Liu Y, Zhang S, Li DW, Jiang SJ. Efficacy of Anti-Interleukin-5 Therapy with Mepolizumab in Patients with Asthma: A Meta-Analysis of Randomized Placebo-Controlled Trials. PloS one. 2013; 8(3):e59872. doi: 10.1371/journal.pone.0059872 PMID: 23544105.

40. Juniper EF, Guyatt GH, Willan A, Griffith LE. Determining a minimal important change in a disease-specific Quality of Life Questionnaire. J Clin Epidemiol. 1994; 47(1):81-7. doi: 10.1016/0895-4356(94) 90036-1 PMID: 8283197.

41. Global Initiative for Asthma. Global strategy for asthma management and prevention, 2016. Available: http://ginasthma.org/wp-content/uploads/2016/04/GINA-2016-main-report_tracked.pdf.

42. Kontopantelis E, Springate DA, Reeves D. A re-analysis of the Cochrane Library data: the dangers of unobserved heterogeneity in meta-analyses. PloS one. 2013; 8(7):e69930. doi: 10.1371/journal.pone. 0069930 PMID: 23922860; PubMed Central PMCID: PMC3724681.

43. Ortega HG, Yancey SW, Mayer B, Gunsoy NB, Keene ON, Bleecker ER, et al. Severe eosinophilic asthma treated with mepolizumab stratified by baseline eosinophil thresholds: a secondary analysis of the DREAM and MENSA studies. Lancet Respir Med. 2016; 4(7):549-56. doi: 10.1016/S2213-2600 (16)30031-5 PMID: 27177493. 